\title{
PROBLEMATIKA IMPLEMENTASI STANDAR NASIONAL INDONESIA (SNI) WAJIB PADA MAINAN ANAK DI KOTA JAKARTA TIMUR
}

\author{
Sari Tri Suprapto \\ E-mail: saritris7@gmail.com \\ Mahasiswa Fakultas Hukum Universitas Sebelas Maret Surakarta \\ Dona Budi Kharisma \\ E-mail: donabudikharisma@staff.uns.ac.id \\ Dosen Fakultas Hukum Universitas Sebelas Maret Surakarta
}

\begin{abstract}
This article aims to determine the factors that hinder the effectiveness of the application of the Indonesian National Standard (SNI) on children's toys. The research methodology used is empirical research, which is researching secondary data at first, then continuing research on primary data in the field or the community. Legal research materials used are primary and secondary legal materials, the technique used in gathering legal materials is depth interviews and document studies or library materials. The results showed that there were factors that hindered the effectiveness of the implementation of the Indonesian National Standard (SNI), which was due to the community being indifferent or not paying attention to the importance of standardization in children's toys besidesthe lack of merchant knowledge to the importance of SNI in children's toys.In the application of SNI, there are inhibiting factors, namely the Law factor indicated by the absence of regional regulations governing mandatory SNI on children's toys, law enforcement factors namely the lack of work ethic in law enforcement, facility and infrastructure factorsare indicated by communication tools that do not yet support the role of law enforcers to maximize their performance, community factors many people who do not know the importance of SNI in children's toys due to the lack of socialization they get, cultural factors are shown by the legal culture or immature legal habits of society so that the effectiveness of the mandatory forefront of SNI is not running optimally.
\end{abstract}

Keywords: SNI; Children Toys; Effectiveness.

\begin{abstract}
Abstrak
Artikel ini bertujuan untuk mengetahui faktor-faktor yang menjadi penghambat efektivitas penerapan Standar Nasional Indonesia (SNI) pada mainan anak. Metodologi penelitian yang digunakan adalah penelitian empiris, yaitu meneliti data sekunder pada awalnya, untuk kemudian dilanjutkan penelitian terhadap data primer di lapangan atau terhadap masyarakat. Bahan penelitian hukum yang digunakan adalah bahan hukum primer dan sekunder, teknik yang digunakan dalam pengumpulan bahan hukum adalah depth interview dan studi dokumen atau bahan pustaka. Hasil penelitian menunjukkan terdapat faktor yang menghambat efektivitas penerapan Standar Nasional Indonesia (SNI) yaitu dikarenakan masyarakat acuh atau tidak memperhatikan betul pentingnya standardisasi pada mainan anak selain itu kurangnya pengetahuan pedagang terkait pentingnya SNI pada mainan anak. Dalam penerapan SNI terdapat faktor-faktor yang menghambat yaitu faktor Undang-Undang ditunjukkan dengan belum adanya peraturan daerah yang mengatur tentang wajib SNI pada mainan anak, faktor penegak hukum yaitu masih kurangnya etos kerja pada penegak hukum, faktor sarana dan prasarana ditunjukkan dengan alat komunikasi yang belum menunjang peranan penegak hukum untuk memaksimalkan kinerjanya, faktor masyarakat yaitu banyak masyarakat yang belum mengetahui pentingnya SNI pada mainan anak dikarenakan kurangnya sosialisasi yang mereka dapatkan, faktor kebudayaan ditunjukkan dengan budaya hukum atau kebiasaan hukum masyarakat yang belum matang sehingga efektivitas penerapan wajib SNI tidak berjalan dengan maksimal.
\end{abstract}

Kata Kunci: SNI; Mainan Anak; Efektivitas. 


\section{A. Pendahuluan}

Tingginya tuntutan arus globalisasi tidak terlepas dari kebutuhan manusia yang tidak pernah terpuaskan, sehingga selalu terikat dengan masalah ekonomi yang tidak akan pernah ada habisnya, dalam rangka memajukan perekonomian nasional khususnya perdagangan dan daya saing internasional, Indonesia meratifikasi persetujuan pembentukan World Trade Organization (WTO) melalui Undang-Undang Nomor 7 Tahun 1994 tentang Pengesahan Agreement Establishing the World Trade Organization (Persetujuan Pembentukan Organisasi Perdagangan Dunia).

Masuknya Indonesia sebagai anggota perdagangan dunia WTO membawa konsekuensi baik eksternal maupun internal. Sebagai konsekuensi eksternal, Indonesia harus mematuhi seluruh hasil kesepakatan dalam forum WTO (Muhammad Sood, 2012: 13-14).Terdapat beberapa persetujuan dalam WTO yang salah satunya adalah Agreement on Technical Barrier to Trade (TBT). Perjanjian TBT adalah perjanjian yang membahas tentang standar dan aturan teknis yang diterapkan tiap-tiap negara atas barang dagangannya agar sesuai dengan pasar internasional. Implikasi yang harus dilakukan Indonesia dalam melaksanakan persetujuan TBT adalah dengan membentuk UndangUndang Nomor 20 Tahun 2014 tentang Standardisasi dan Penilaian Kesesuaian.

Perangkat standardisasi berperan pula dalam menunjang kemampuan produksi khususnya peningkatan perdagangan dalam negeri dan luar negeri, serta pengembangan industri dan perlindungan konsumen. Penerapan SNI pada dasarnya bersifat sukarela, namun untuk keperluan melindungi kepentingan umum, keamanan negara, perkembangan ekonomi nasional, dan pelestarian fungsi lingkungan hidup, pemerintah memberlakukan SNI secara wajib. Pemberlakuan SNI wajib dilakukan melalui penerbitan regulasi teknis oleh instansi pemerintah yang memiliki kewenangan untuk meregulasi kegiatan dan peredaran produk (regulator). Dalam hal ini, kegiatan dan produk yang tidak memenuhi ketentuan SNI menjadi terlarang. (http://www.bsn.go.id/main/bsn/ isi_bsn/17, diakses 14 Oktober 2018).

Berdasarkan semangat melindungi negara tersebut, salah satu dari sekian jenis barang yang ditetapkan wajib SNI adalah mainan. Pemerintah mengeluarkan Peraturan Menteri Perindustrian No. 24M-IND/PER/4/2013 tentang Pemberlakuan Standar Nasional Indonesia (SNI) Mainan Secara Wajib yang telah diubah menjadi Peraturan Menteri Perindustrian No. 55/M-IND/PER/11/2013 tentang Pemberlakuan Standar Nasional Indonesia (SNI) Mainan Secara Wajib. Tujuan dibentuknya peraturan terkait standardisasi mainan ini adalah untuk memberikan rasa aman pada anak dan orang tua tentunya mengingat banyaknya mainan baik dari dalam negeri maupun luar negeri yang diperjualbelikan secara bebas di Indonesia.

Pengaturan mengenai mainan anak ini menjadi penting mengingat anak-anak sangat rentan terhadap penyakit yang diakibatkan oleh zat tertentu pada mainan. Namun dibalik bebasnya peredaran mainan anak-anak di Indonesia, hal tersebut masih menyimpan polemik dan celah yang jamak dilakukan di masyarakat. Pedagang mainan anak di Kota Jakarta Timur masih belum mengerti akan pentingnya standardisasi (pemberian SNI), selain itu para produsen dan pedagang mainan anak menganggap bahwa melakukan standardisasi akan memakan biaya yang besar dan dapat meningkatkan harga jual mainan yang dikhawatirkan akan mengurangi laba mereka oleh sebab itu masih banyak mainan-mainan yang belum memiliki standar dan membahayakan untuk anak-anak (Merita Bernik, Wa Ode Zusnita, 2017:47). Berdasarkan Uraian di atas artikel ini membahas mengenai faktor-faktor yang menjadi penghambat efektivitas penerapan Standar Nasional Indonesia (SNI) wajib untuk mainan anak.

\section{B. Metode Penelitian}

Jenis penelitian yang digunakan penulis adalah jenis penelitian empiris yaitu penelitian yang awalnya meneliti data sekunder, untuk kemudian dilanjutkan dengan penelitian terhadap data primer di lapangan, atau terhadap masyarakat (Soerjono Soekanto, 2014:52). Teknik pengumpulan data yang digunakan adalah Wawancara-Mendalam (In-depth Interview) dan studi dokumen atau bahan pustaka. 


\section{Hasil Penelitian dan Pembahasan}

Undang-Undang Nomor 20 Tahun 2014 tentang Perindustrian memberikan wewenang pada setiap instansi untuk membuat peraturan terkait barang yang wajib di standardisasi. Dalam Undang-Undang Nomor 20 Tahun 2014 pada Pasal 24 ayat (2) dikatakan bahwa pemberlakuan Standar Nasional Indonesia adalah keputusan pimpinan instansi teknis yang berwenang untuk memberlakukan Standar Nasional Indonesia secara wajib terhadap barang dan atau jasa.

Pemberlakuan SNI secara wajib adalah regulasi teknis atas barang dan atau jasa yang ditetapkan oleh Menteri dan diberlakukan secara wajib di seluruh wilayah Negara Kesatuan Republik Indonesia. Namun, sebagian SNI dapat diwajibkan penerapannya apabila ia berhubungan erat dengan keamanan, keselamatan kerja dan kelestarian lingkungan hidup (disebut dengan SNI wajib) (M. Azaw Massijaya dkk, 2010:119).

Mainan anak dalam hal ini termasuk dalam kategori objek yang wajib terstandardisasi, hal ini berdasarkan Peraturan Menteri Perindustrian No. 55/M-IND/PER/11/2013 tentang Standar Nasional Indonesia (SNI) Mainan Secara Wajib. Pemerintah mengeluarkan peraturan tersebut untuk mengatur standardisasi mainan mulai dari masuk barang/produksi, pemberian standar, sampai dengan beredarnya produk ke masyarakat.

Namun, agar suatu peraturan yang dibuat pemerintah dapat berjalan dengan baik dan efektif perlu ada pengetahuan bukan hanya dari pihak pedagang atau pemilik usaha tetapi konsumen harus memiliki pengetahuan yang lebih luas terkait pentingnya membeli barang yang memiliki sertifikat SNI. Jangan sampai pedagangnya paham, namun konsumennya tidak mengerti akan pentingnya mainan berstandar atau mainan ber-SNI.

Menilik kembali teori efektivitas hukum menurut Lawrence yaitu Legal Structure atau Struktur Hukum yang melihat suatu peraturan menjadi efektif jika peran dari penegak hukum sudah maksimal dalam melaksanakan tugasnya. Selaras dengan teori Lawrence, Soerjono Soekanto juga mengemukakan bahwasanya penerapan hukum telah efektif jika mendapat dukungan sarana dan prasarana yang memadai untuk mendukung peranan penegak hukum. Masyarakat yang belum mengetahui akan pentingnya membeli dan menjual mainan ber-SNI ini adalah buntut dari struktur hukum yang belum maksimal dalam melakukan tugasnya ditambah dengan kurangnya pemanfaatan sarana dan prasarana yang memadai untuk menginformasikan terkait peraturan wajib SNI pada mainan anak. Hal ini dapat menyebabkan penerapannya menjadi tidak efektif dan tentu dapat merugikan, baik kepada pedagang itu sendiri, masyarkat selaku konsumen, maupun pemerintah selaku regulator.

Menurut teori Soerjono Soekanto, hukum dikatakan telah berjalan secara efektif jika telah memenuhi kelima unsur yaitu Undang-Undang, Penegak Hukum, Sarana dan Pra-sarana, Masyarakat, dan Budaya. Berangkat dari teori tersebut, berikut adalah faktor-faktor yang menjadi penghambat impelementasi wajib SNI pada penjual mainan di Jakarta Timur:

\section{Undang-Undang}

Hukum berfungsi untuk keadilan, kepastian dan kemanfaatan. Dalam praktik penyelenggaraan hukum di lapangan ada kalanya terjadi pertentangan antara kepastian hukum dan keadilan. Kepastian Hukum sifatnya konkret berwujud nyata, sedangkan keadilan bersifat abstrak sehingga ketika seseorang hakim memutuskan suatu perkara secara penerapan Undang-Undang saja maka ada kalanya nilai keadilan itu tidak tercapai. Maka ketika melihat suatu permasalahan mengenai hukum setidaknya keadilan menjadi prioritas utama. Karena hukum tidaklah semata-mata dilihat dari sudut hukum tertulis saja.

Di Kota Administrasi Jakarta Timur, belum ada peraturan daerah yang khusus mengatur tentang wajib SNI pada mainan anak. Mengingat Kota Jakarta Timur adalah kota administrasi yang berinduk di bawah Provinsi DKI Jakarta, maka seharusnya Walikota lebih proaktif untuk melihat permasalahan seperti ini. Seharusnya diterbitkan Peraturan Daerah yang mengatur 
akan pentingnya standardisasi pada mainan anak. Bukan hanya mengarah pada perlindungan konsumen, namun lebih jauh lagi dengan dikeluarkannya dasar hukum yang jelas akan berdampak pada peningkatan daya saing pedagang itu sendiri.

Masih rendahnya tingkat daya saing di Indonesia, rendahnya kepatuhan pelaku usaha dalam penerapan $\mathrm{SNI}$, dan era perdagangan bebas menjadi landasan sosiologis perlunya pembentukan regulasi daerah tentang standar dan penilaian kesesuaian. Peraturan daerah merupakan wujud konkret dari hukum. Pembentukan peraturan perundang-undangan harus sesuai dengan kenyataan, fenomena, perkembangan dan keyakinan atau kesadaran serta kebutuhan hukum masyarakat. Selain itu, masyarakat saat ini membutuhkan regulasi daerah yang berfungsi sebagai acuan utama dan metode penerapan SNI menyebabkan pembangunan di bidang industri yang dilakukan oleh pemerintah daerah masih bersifat parsial dan belum terintegrasi. Berbagai program kebijakan peningkatan daya saing produk unggulan daerah belum ada acuan, model dan bentuk penerapan standar dan penilaian kesehatan yang diselenggarakan oleh semua komponen di daerah. Komponen tersebut meliputi : pemerintah daerah, BSN, Lembaga Sertifikasi, Swasta, BUMN dan koperasi. Regulasi daerah tentang standar dan penilaian kesesuaian akan membuat penyelenggaraan urusan bidang perindustrian di daerah lebih terarah, tersistem dan komprehensif.

\section{Penegak Hukum}

Dalam berfungsinya hukum, mentalitas atau kepribadian petugas penegak hukum memainkan peranan penting, kalau peraturan sudah baik, tetapi kualitas petugas kurang baik, ada masalah. Selama ini ada kecenderungan yang kuat di kalangan masyarakat untuk mengartikan hukum sebagai petugas atau penegak hukum, artinya hukum diidentikkan dengan tingkah laku nyata petugas atau penegak hukum. Sayangnya dalam melaksanakan wewenangnya sering timbul persoalan karena sikap atau perlakuan yang dipandang melampaui wewenang atau perbuatan lainnya yang dianggap melunturkan citra dan wibawa penegak hukum. Hal ini disebabkan oleh kualitas yang rendah dari aparat penegak hukum tersebut.

Dalam kasus efektivitas penerapan wajib SNI pada mainan anak di Kota Jakarta Timur, faktor Penegak Hukum memang tidak menjadi sorotan. Penegak Hukum yang dalam hal ini adalah para petugas dari Dinas Perindustrian selaku dinas yang berwenang dalam pengawasan SNI di wilayah Kota Jakarta Timur selalu menjunjung tinggi prosedur pekerjaan yang berlaku. Akan tetapi yang perlu digarisbawahi dan justru menjadi faktor penghambat adalah etos kerja dari para penegak hukum tersebut.

Etos kerja yang dimaksud adalah rasa keuletan dan kerja keras yang harus ditanam dalam diri masing-masing penegak hukum yang bertugas mengawasi penerapan SNI pada mainan anak. Jika para penegak hukum tersebut mempunyai etos kerja yang baik tentu mereka akan dengan giat menyebarkan informasi terkait pentingnya menjual ataupun membeli mainan anak yang ber-SNI. Pada faktanya, memang masih ada pedagang dan masyarakat yang tidak mengetahui bahwa mainan anak harus sudah terstandardisasi. Hal ini adalah buntut dari kurangnya etos kerja penegak hukum yang tidak mau secara proaktif mensosialisasikan wajib SNI pada mainan anak.

Jika melihat pada kondisi yang ada, penegak hukum yang dalam hal ini adalah para petugas dari Dinas Perindustrian Kota Jakarta Timur ini cenderung pasif dan tidak berinisiatif untuk turun langsung ke masyarakat khususnya pedagang untuk mensosialisasikan pentingnya mainan ber-SNI. Seharusnya program-program yang bersifat preventif seperti itu lebih banyak dilakukan dari pada hanya sosialisasi musiman yang terkesan hanya formalitas saja tanpa mempedulikan hasil yang bisa dicapai dari sosialisasi tersebut. Intensifitas dan keberlanjutan sosialisasi ini penting mengingat untuk membangun sebuah kebiasaan diperlukan program yang sifatnya berkesinambungan, bukan program dadakan dan hanya bersifat musiman. 


\section{Faktor Sarana dan Prasarana}

Faktor sarana atau fasilitas pendukung mencakup perangkat lunak dan perangkat keras, Menurut Soerjono Soekanto bahwa para penegak hukum tidak dapat bekerja dengan baik, apabila tidak dilengkapi dengan kendaraan dan alat-alat komunikasi yang proporsional. Oleh karena itu, sarana atau fasilitas mempunyai peranan yang sangat penting di dalam penegakan hukum. Tanpa adanya sarana atau fasilitas tersebut, tidak akan mungkin penegak hukum menyerasikan peranan yang seharusnya dengan peranan yang aktual.

Faktor sarana dan prasarana juga menjadi satu dari sekian faktor yang menghambat penerapan wajib SNI pada mainan anak di Kota Jakarta Timur. Faktor sarana dan prasarana ini menghambat para penegak hukum (Petugas Dinas Perindustrian) untuk menjalankan fungsinya sebagai alat pemerintah daerah untuk mengawasi penerapan wajib SNI pada mainan anak, hal ini dikarenakan para penegak hukum tidak dibekali dengan peralatan komunikasi yang menunjang sesuai dengan perkembangan zaman sekarang ini.

Sarana dan prasarana tersebut seharusnya disediakan agar para penegak hukum bisa menjalankan fungsinya dengan maksimal. Jika alat komunikasi yang digunakan terus mengikuti perkembangan zaman, maka pesan yang ingin disampaikan pun akan dengan mudah diterima oleh masyarakat baik itu pedagang maupun konsumen secara umum. Jika dibandingkan dengan cara komunikasi konvensional yang mengharuskan datang dan tatap muka, maka akan memakan waktu dan biaya yang tidak sedikit pula, pun target yang dapat menyerap pesannya tidak bisa sebanyak penggunaan alat komunikasi yang modern.

Selain pada sisi penegak hukum, sarana dan prasarana harus juga mendukung para pedagang dan masyarakat sebagai pihak yang mendistribusikan dan menggunakan mainan. Seharusnya disediakan fasilitas konsultasi untuk pedagang ataupun masyarakat yang khusus terkait dengan $\mathrm{SNI}$ ini. Dengan adanya fasilitas konsultasi seperti ini pedagang dapat dipandu untuk mengimplementasikan wajib SNI pada dagangannya, dan masyarakat pun bisa teredukasi dengan datang dan menanyakan apakah mainan yang mereka gunakan sudah aman dan sesuai dengan prosedur.

Dengan maksimalnya pemanfaatan sarana dan prasarana baik pada penegak hukum maupun pada pedagang dan masyarakat, maka akan berbanding lurus dengan penegakan aturan wajib SNI itu sendiri. Dengan begitu efektivitias penerapan wajib SNI pada mainan anak di Kota Jakarta Timur pun akan berjalan dengan baik dan kepastian hukum akan tercipta dengan sendirinya.

\section{Masyarakat}

Penegak hukum berasal dari masyarakat dan bertujuan untuk mencapai kedamaian di dalam masyarakat. Setiap warga masyarakat atau kelompok sedikit banyaknya mempunyai kesadaran hukum. Persoalan yang timbul adalah taraf kepatuhan hukum, yaitu kepatuhan hukum yang tinggi, sedang, atau kurang. Adanya derajat kepatuhan hukum masyarakat terhadap hukum, merupakan salah satu indikator berfungsinya hukum yang bersangkutan.

Kepatuhan masyarakat terkait wajib SNI pada mainan anak khususnya pedagang masih sangat minim. Hal ini diakibatkan karena kurangnya sosialisasi yang didapat oleh mereka. Ketidaktahuan ini, berdampak pada efektivitas penerapan wajib SNI pada mainan anak di Kota Jakarta Timur yang tidak berjalan dengan baik. Sosialisasi yang tidak maksimal tersebut mengakibatkan masyarakat menjadi tidak mematuhi hukum yang berlaku.

Terdapat kelompok masyarakat yang mengakibatkan tidak efektifnya penerapan wajib SNI pada mainan anak ini adalah:

a. Masyarakat sebagai Pelaku Usaha

Berdasarkan hasil dari penelitian di Dinas Perindustrian dan Energi Kota Administrasi Jakarta Timur, sosialisasi yang minim mengakibatkan para pedagang mainan tidak mengerti bahwa mainan-mainan itu dilindungi Undang-Undang. Kurangnya sosialisasi 
yang dilakukan kepada pedagang secara menyeluruh yang notabene adalah pihak yang sangat berperan dalam rantai peredaran mainan sangatlah mempengaruhi terhambatnya implementasi wajib menjual mainan anak ber-SNI di Kota Administrasi Jakarta Timur. Hal ini dikarenakan para pedagang menganggap bahwa hal tersebut tidak terlalu penting, mengingat pembelinya tetap datang. Menurut penulis, seharusnya Dinas Perindustrian dan Energi Kota Administrasi Jakarta Timur harus lebih proaktif untuk melakukan sosialisasi terkait standardisasi khususnya standardisasi mainan anak. Sosialisasi terebut perlu dilakukan untuk menambah wawasan para pedagang di wilayah Kota Jakarta Timur bahwasanya menjual mainan anak yang tidak terstandardisasi adalah dilarang oleh Undang-Undang dan Peraturan lain yang mengatur tentang itu. Dengan melakukan sosialisasi yang menyeluruh dan intensif maka implementasi wajib menjual mainan anak ber-SNI bisa maksimal.

\section{b. Masyarakat sebagai konsumen}

Berdasarkan hasil penelitian di Dinas Perindustrian dan Energi Kota Administrasi Jakarta Timur, pihak dinas dalam rentan tahun 2015-2018 belum pernah melakukan sosialisasi terkait standardisasi khususnya standardisasi mainan ke masyarakat umum. Fenomena tersebut menunjukkan bahwa masyarakat dalam hal ini masih dipandang sebelah mata dalam hal kesadaran akan pentingnya menggunakan dan membeli mainan anak berstandar. Hal ini ditunjukkan dengan sosialisasi yang belum pernah dilakukan ke masyarakat, alhasil masyarakat masih banyak yang tidak begitu mempedulikan mainan yang dibelinya sudah ber-SNI atau belum. Fakta tersebut diperkuat dengan penuturan pedagang baik yang ada di dalam Pasar Gembrong dan yang di luar lingkungan pasar, mereka menuturkan bahwa jarang sekali masyarakat (konsumen) menanyakan apakah mainan di toko mereka sudah ber-SNI atau belum. Masyarakat cenderung abai akan pentingnya standardisasi pada mainan, dan membeli mainan tanpa memperhatikan hal tersebut. Dapat dilihat bahwa seharusnya Dinas Perindustrian dan Energi Kota Administrasi Jakarta Timur aktif melakukan sosialisasi bukan hanya kepada pedagang saja, melainkan lebih gencar melakukan sosialisasi-sosialisasi akan pentingnya mainan anak berstandar pada masyarakat yang notabene membeli dan menggunakannya secara langsung. Hal ini supaya peraturan yang ada menjadi efektif penerapannya di masyarakat sesuai dengan teori yang dikemukakan oleh Lawrence dan Soerjono Soekanto yang sepakat memasukkan unsur Budaya dan Masyarakat sebagai indikator telah efektifnya sebuah peraturan hukum. Jika masyarakat mentaati dan mendukung sebuah peraturan, maka dapat dikatakan bahwa peraturan hukum tersebut sudah efektif.

\section{Budaya}

Kebudayaan pada dasarnya mencakup nilai-nilai yang mendasari hukum yang berlaku, nilai-nilai mana yang merupakan konsepsi-konsepsi yang abstrak mengenai apa yang dianggap baik (sehingga dituruti) dan apa yang dianggap buruk (sehinga dihindari). Maka, kebudayaan Indonesia merupakan dasar atau mendasari hukum adat yang berlaku. Disamping itu berlaku pula hukum tertulis (perundang-undangan), yang dibentuk oleh golongan tertentu dalam masyarakat yang mempunyai kekuasaan dan wewenang untuk itu. Hukum perundangundangan tersebut harus dapat mencerminkan nilai-nilai yang menjadi dasar dari hukum adat, agar hukum perundang-undangan tersebut dapat berlaku secara aktif.

Efektif atau tidaknya peraturan terkait wajib menjual mainan anak yang berstandar dilihat dari bagaimana kesadaran masyarakat dan pedagang akan pentingnya budaya hukum dalam perilaku kehidupan sehari-hari. Istilah budaya hukum muncul seiring dengan perkembangan lebih lanjut dari studi hukum dan masyarakat serta kebudayaan. Thurnwald, yang dikutip oleh Soekanto, mengemukakan bahwa hukum harus dianggap sebagai ekspresi suatu sikap kebudayaan, artinya tertib hukum harus dipelajari dan dipahami secara fungsional dari sistem kebudayaan (Budi Agus Riswandi dan M. Syamsudin, 2004 : 145) 
Menurut Darmodiharjo dan Shidarta, budaya hukum identik dengan pengertian kesadaran hukum, yaitu kesadaran hukum dari subjek hukum secara keseluruhan. Indikator-indikator kesadaran hukum tersebut adalah sebagai berikut (Budi Agus Riswandi dan M. Syamsudin, $2004: 158)$ :

1) Pengetahuan tentang peraturan-peraturan hukum (law awareness);

2) Pengetahuan tentang isi peraturan hukum (law acquaintance);

3) Sikap terhadap peraturan-peraturan hukum (legal attitude);

4) Pola perilaku hukum (legal behavior).

Berdasarkan pengertian tersebut, kendala-kendala dalam implementasi wajib menjual mainan anak terstandardisasi juga disebabkan oleh budaya hukum yang selama ini sudah mengakar pada masyarakat di Indonesia. Tingkat kesadaran, pengetahuan, dan kepatuhan masyarakat yang masih rendah, dan kebiasaan yang sudah dilakukan sejak lama serta berulang-ulang adalah faktor-faktor yang menyebabkan budaya hukum di Indonesia menjadi lebih mengedepankan hal-hal tersebut dibandingkan dengan peraturan formal yang telah ditetapkan.

Solusi yang harus dilakukan oleh Dinas Perindustrian dan Energi Kota Administrasi Jakarta Timur adalah memberikan sosialisasi secara terus menerus khususnya pada para produsen mainan anak dan masyarakat. Tindakan aktif DinasPerindustrian dan Energi dapat melakukan building character kepada semua pihak terkait guna meningkatkan kesadaran, kepatuhan, serta ketaatan terhadap peraturan-peraturan yang telah ditetapkan dalam Undang-Undang Standardisasi, ataupun peraturan lain yang berhubungan dengan standardisasi mainan anak.

\section{Simpulan}

Terdapat faktor-faktor penghambat yang menyebabkan kurang maksimalnya implementasi SNI wajib pada mainan anak, yaitu Pertama, Undang-Undang (belum adanya peraturan daerah yang mengatur tentang wajib SNI pada mainan anak). Kedua, Penegak Hukum (etos kerja dari petugas yang kurang). Ketiga, Sarana dan Prasarana (alat komunikasi yang belum menunjang peranan penegak hukum untuk memaksimalkan kinerjanya). Keempat, Masyarakat (Masyarakat yang belum tahu mengenai pentingnya wajib SNI pada mainan anak akibat kurangnya sosialisasi), dan Kelima, Budaya (budaya hukum atau kebiasaan hukum masyarakat yang belum matang sehingga efektivitas penerapan wajib SNI pada mainan anak di Kota Jakarta Timur menjadi tidak maksimal).

\section{E. Saran}

Pemerintah Kota Jakarta Timur melalui Dinas Perindustrian dan Energi Kota Administrasi Jakarta Timur lebih aktif dalam mengenalkan apa itu standardisasi mainan. Langkah-langkah yang bisa dilakukan adalah dengan mengadakan sosialisasi dalam bentuk workshop, bazar, dan lainlain, yang melibatkan para pedagang serta masyarakat yang bertemakan standardisasi dan bekerja sama dengan organisasi perangkat daerah (OPD) seperti dinas pariwisata, dinas perindustrian, dan dinas perekonomian untuk kemudian memasang atau menyebar slogan-slogan yang bertemakan standardisasi mainan secara wajib. Dengan gencar mengkampanyekan pentingnya standardisasi mainan anak secara wajib, kesadaran hukum masyarakat akan tumbuh dengan sendirinya. Seiring dengan tumbuhnya kesadaran hukum, maka implementasi standardisasi mainan anak secara wajib dapat berjalan dengan maksimal.

\section{F. Daftar Pustaka}

Soerjono Soekanto. 2004. Faktor-faktor yang mempengaruhi Penegakan Hukum. Jakarta: Raja Gafindo Persana. 
AL. Sentot Sudarwanto, Dona Budi Kharisma, Ambar Budhi Sulistyawati. 2019. Hukum Perindustrian Indonesia. Yogyakarta: Thafa Media.

Dona Budi Kharisma, Ambar Budi S, Al. Sentot Sudarwanto. 2018. "Proceeding of International Conference on Small and Medium Enterprise Empowerment 2018", Industry Standardization and Competitiveness of MSMEs in the Era of Creative Economy.

Dona Budi Kharisma, M. Najib Imanullah, Pranoto. 2017. "Standard and Conformity: The Perspective Strategies of The Local Government's Roles in the Industry Competitiveness". Yustisia Journal. Vol. 6 No. 2, May-August. Surakarta: Fakultas Hukum Universitas Sebelas Maret.

Merita Bernik. 2017. "Model of Quality Management System to Maintain Quality Consistency in Higher Educaton". Review of Integrative \& Business Economics Research (RIBER), Rev. Integrated Business, Econ.Res,. Vol 6 (4). Bandung: Fakultas Ekonomi dan Bisnis Universitas Padjajaran.

Merita Bernik, Wa Ode Zusnita. 2017. "Quality Assurance and Safety for Children Toys". International Journal of Business and Management. Vol 1 (2). Bandung: Fakultas Ekonomi dan Bisnis Universitas Padjajaran.

Muh. Azaw Massijaya. 2010. "Pemilihan SNI Wajib Sebagai Objek Penelitian dengan Metode Analytic Hierarchy Process (AHP)". Jurnal Standardisasi. Vol. 17 (2).

Undang-Undang Nomor 20 Tahun 2014 tentang Standardisasi dan Penilaian Kesesuaian

Peraturan Menteri Perindustrian Nomor 55 Tahun 2013 tentang Standar Nasional Indonesia (SNI) Mainan Secara Wajib

Peraturan Menteri Perindustrian Nomor 24 Tahun 2013 tentang Standar Nasional Indonesia (SNI) Mainan Secara Wajib

http://bsn.go.id/main/bsn/isi_bsn/15, (diakses pada 14 Oktober 2018, pukul 15.30 WIB) 